\title{
DRt 0041.8
}

DOE/JPL/956615-84-1

(DE84009178)

\section{LASER-ASSISTED SOLAR CELL METALLIZATION PROCESSING}

Quarterly Report for the Period September 13-December 12, 1983

By

S. Dutta
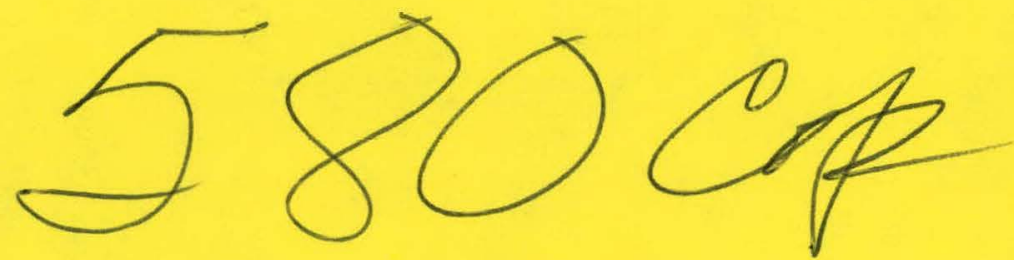

January 16, 1984

Work Performed Under Contract No. NAS-7-100-956615

Westinghouse R\&D Center

Churchill, Pennsylvania

Technical Information Center

Office of Scientific and Technical Information United States Department of Energy 


\section{DISCLAIMER}

This report was prepared as an account of work sponsored by an agency of the United States Government. Neither the United States Government nor any agency Thereof, nor any of their employees, makes any warranty, express or implied, or assumes any legal liability or responsibility for the accuracy, completeness, or usefulness of any information, apparatus, product, or process disclosed, or represents that its use would not infringe privately owned rights. Reference herein to any specific commercial product, process, or service by trade name, trademark, manufacturer, or otherwise does not necessarily constitute or imply its endorsement, recommendation, or favoring by the United States Government or any agency thereof. The views and opinions of authors expressed herein do not necessarily state or reflect those of the United States Government or any agency thereof. 


\section{DISCLAIMER}

Portions of this document may be illegible in electronic image products. Images are produced from the best available original document. 


\title{
DISCLAIMER
}

\begin{abstract}
This report was prepared as an account of work sponsored by an agency of the United States Government. Neither the United States Government nor any agency thereof, nor any of their employees, makes any warranty, express or implied, or assumes any legal liability or responsibility for the accuracy, completeness, or usefulness of any information, apparatus, product, or process disclosed, or represents that its use would not infringe privately owned rights. Reference herein to any specific commercial product, process, or service by trade name, trademark,

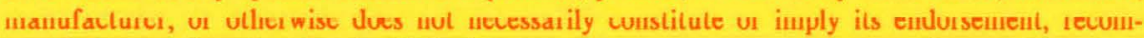
mendation, or favoring by the United States Government or any agency thereof. The views and opinions of authors expressed herein do not necessarily state or reflect those of the United States Government or any agency thereof.
\end{abstract}

This report has been reproduced directly from the best available copy.

Available from the National Technical Information Service, U. S. Department of Commerce, Springfield, Virginia 22161.

Price: Printed Copy A02

Microfiche A01

Codes are used for pricing all publications. The code is determined by the number of pages in the publication. Information pertaining to the pricing codes can be found in the current issues of the following publications, which are generally available in most libraries: Energy Research Abstracts (ERA); Government Reports Announcements and Index (GRA and 1); Scientific and Technical Abstract Reports (STAR); and publication NTIS-PR-360 available from NTIS at the above address. 
DOE/JPL/956615-84-1

(DE84009178)

Distribution Category UC.63b

LASER-ASSISTED SOLAR CELL

METALLIZATION PROCESSING

S. Dutta

Quarterly Report for the Period September 13

to December 12, 1983

Jet Propu1sion Laboratory

Contract No. 956615

January 16,1984 
CONTENTS

LIST OF FIGURES................................

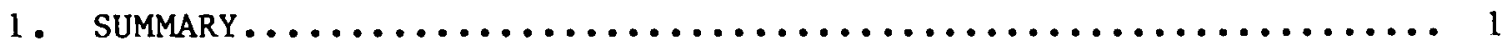

1,1 Literature Search........................... 3

1.1.1 Photód1ssoclalion Metal Depositinn............. 3

1.1.2 Pyrolytic Metal Deposition.................. 4

1.1:3 Laser-Assisted Electruplating................. ;

1.2 Design and Construction of the Laser Photolysis System.... 5

1.3 Summary of Laser-Enhanced Electroplating Results......... 10

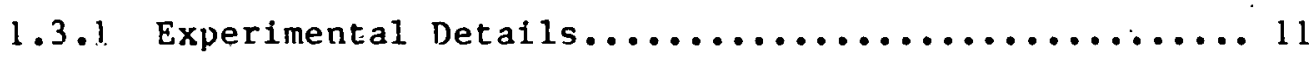

2. CONCLUSIONS AND RECOMMENDATIONS $\ldots \ldots \ldots \ldots \ldots \ldots \ldots \ldots \ldots \ldots \ldots \ldots$

3. PROJECTION OF ACTIVITIES FOR SECOND QIJARTER............. 17

4. REFERENCES................................... 18 
$\underline{\text { Yage }}$

Figure 1. Milestone Chart 2

Figure 2. Top view of gas-fill and pumplng station. 6

Figure 3. Cross section of gas-fill and pumping station. 7

Figure 4 . Schematic of sample chamber. 8

Figure 5. Schematic of experimental set-up for
laser-assisted photolysis.

Figure 6. 150X Nomarski micrograph of smallest plated spot. 10

Figure 7. 100X Nomarski micrograph of line plated using single
slow scan.

Figure 8. 200X Nomarski micrograph of line plated using multiple rapid scans. 


\section{SUMMARY}

The Westinghouse Flectric Corporation has undertaken, in JPL Contract No. 956615, to investigate, develop, and characterize laserassisted processing techniques utilized to produce the fine line, thin metal grid structures that are required to fabricate high-efficiency solar cells. Two basic techniques for metal deposition will be investigated, as follows: (1) photochemical decomposition of liquid or gas phase organometallic compounds utilizing either a focused, CW ultraviolet laser (System 1) or a mask and ultraviolet flood illumination, such as that provided by a repetitively pulsed, defocused excimer laser (System 2), for pattern definition, and (2) thermal deposition of metals from organometallic solutions or vapors utilizing a focused, $\mathrm{CW}$ laser beam as a local heat source to draw the metallization pattern.

The purpose of this contract is to investigate the various existing laser-assisted film deposition techniques in order to develop a new, cost-effective technology for solar cell metallization. The tasks that will be performed in the conduct of these investigations are detailed below and summarized in the milestone chart in Figure 1.

In the first three months of this contract, a comprehensive literature search has been carried out on the various state-of-the-art laser-assisted techniques for metal deposition, including laser chemical vapor deposition and laser photolysis of organometallics, as well as laser-enhanced electroplating. A compact system for the experiments involving laser-assisted photolysis of gas-phase compounds has been designed and constructed. Initial experiments on laser-enhanced electro-plating have yielded very promising results, with linewidths as fine as $25 \mu \mathrm{m}$ and plating speeds as high as $12.11 \mathrm{~m} / \mathrm{ser}$ heing achieved. 
MILESTONE CHART

JPL CONTRACT 956615

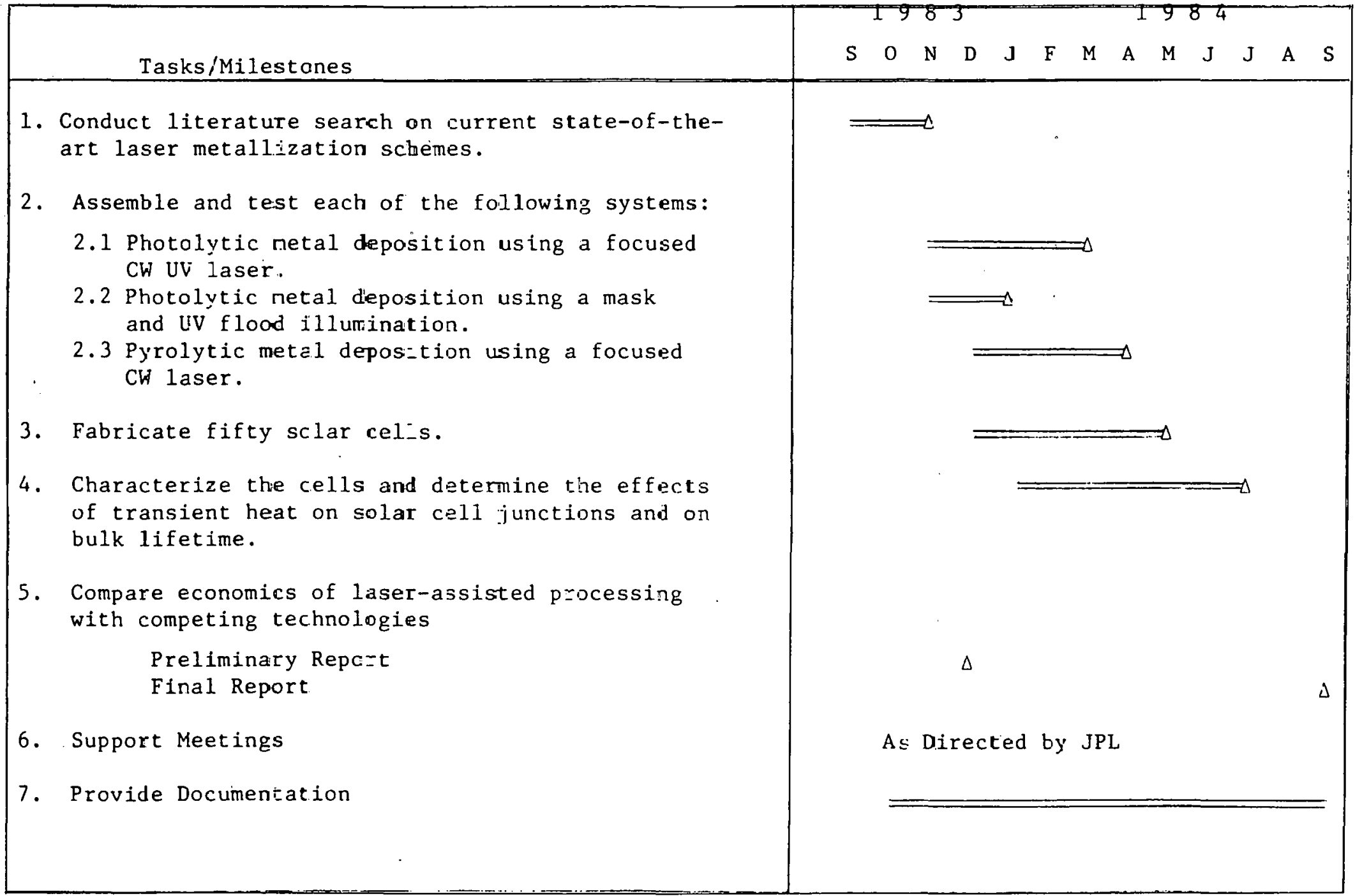




\subsection{Literature Search}

The results of the literature survey are briefly summarized in the following paragraphs.

\subsubsection{Photodissociation Metal Deposition}

Laser-induced photodecomposition of gas-phase organometallic compounds is fundamentally a nonthermal process, involving multiphoton absorption by the compound, which then dissociates, liberating metal atoms in the vicinity of a suitable substrate. These atoms then condense onto the illuminated regions of the substrate forming a metal film. Localization of the substrate illumination is achieved either by focusing the laser or by using flood illumination in conjunction with a mask.

Draper $(1)$ has deposited both $\mathrm{Cr}$ and Mo using off-resonance laser-induced dielectric breakdown of metal-carbonyl vapors with a pulsed $\mathrm{CO}_{2}$ laser. Solanki et al. (2) used a pulsed copper hollow cathode laser at $260 \mathrm{~nm}$, utilizing the multiphoton absorption that occurs at this ultra-violet wavelength for carbonyl molecules, to deposit $\mathrm{Cr}$, Mo, and $W$ films. The laser was operated at $150 \mathrm{~mW}$ peak power with pulse widths of 120 ils. Ehrlich, Deutsch, and 0sgood $(3-6)$ have performed a variety of experiments using both pulsed (excimer lasers, 1-100 mJ, 10 $\mathrm{ns}$ ) and $\mathrm{CW}$ (frequency-doubled $\mathrm{Ar}^{+}$laser, $10 \mathrm{wW}-3$ ) IV lasers. Tn one of their most interesting experiments, (4) a two-step process was used to deposit patterned $\mathrm{Cd}, \mathrm{Al}$, and $\mathrm{Zn}$ films from metal-alkyl vapors. In the first step, localized pre-nucleation was achieved by using a focused UV laser to irradiate the substrate in the requisite pattern, photodissociating a thin, adsorbed layer of metal-alkyl molecules. The laser was then defocused to illuminate the entire substrate, causing film growth to occur selectively in the pre-nucleated regions. These experiments also indicated that films of one metal, e.g., Al, could be grown on nucleation centers of a second, dissimilar metal, e.g., $\mathrm{Zn}$. Table 1 lists the encapsulant gases Ehrlich et al. used in their experiments. 
Table 1

Encapsulant Gases Used by M.I.T. Lincoln Laboratory for Photodissociation

$\begin{array}{llll}\mathrm{Cd} & \left(\mathrm{CH}_{3}\right)_{2} & \mathrm{Fe}(\mathrm{CO})_{5} & \mathrm{CF}_{3} \mathrm{I} \\ \mathrm{Zn} & \left(\mathrm{CH}_{3}\right)_{2} & \mathrm{~W}(\mathrm{CO})_{6} & \mathrm{SnC}_{4} \\ \mathrm{Sn} & \left(\mathrm{CH}_{3}\right)_{4} & \mathrm{Cr}(\mathrm{CO})_{6} & \\ \mathrm{Ga}\left(\mathrm{CH}_{3}\right)_{3} & & \\ \mathrm{Bi}\left(\mathrm{CH}_{3}\right)_{3} & & \\ \mathrm{Si}\left(\mathrm{CH}_{3}\right)_{4} & & \\ \mathrm{Ge}\left(\mathrm{CH}_{3}\right)_{4} & & \\ \mathrm{Al} & \left(\mathrm{CH}_{3}\right)_{6} & & \end{array}$

In another set of experiments, Coombe and Wodarczyk (7) used KrF (249 nm) and $\mathrm{XeCl}(308 \mathrm{~nm}$ ) excimer lasers to induce the localized deposition of $\mathrm{Zn}$ and $\mathrm{Mg}$ films from the pure metal vapors: The laser pulses used in these experiments were typically $20 \mathrm{~ns}$ in duration and carried energies of up to $20 \mathrm{~mJ}(\mathrm{KrF})$ or $5 \mathrm{~mJ}(\mathrm{XeCl})$.

\subsubsection{Pyrolytic Meta1 Deposition}

Chemical vapor deposition (CVD) of metals is conventionally accomplished by resistively or inductively heating an appropriate substrate in a reactive atmosphere, with pyrolysis reactions at the substrate surface providing the basis for film growth. Laser chemical vapor deposition (LCVD) is achieved by using pulsed or CW lasers of suitable wavelengths to selectively heat localized areas of substrates which absorb at those wavelengths, areas adjacent to the illuminated regions remaining comparatively cool. Allen and $\mathrm{Bass}^{(8)}$ have used a $\mathrm{CO}_{2}$ laser to deposit nickel on quartz substrates from gaseous $\mathrm{Ni}(\mathrm{CO})_{4} \cdot \mathrm{LCVO}$ metal thicknesses tend to be self-limiting, with a maximum thickness of $550 \AA$ being obtained for nickel. 


\subsubsection{Laser-Assisted Electroplating}

Another new laser-processing technique that ts of interest in this program is laser-assisted electroplating. Maskless plating was achieved by von Gutfield et al., (9) utilizing a CW or pulsed laser focused onto an electroplating bath. Local plating enhancement rates as high as $\sim 10^{3}$ have been obtained by this technique. A CW multimode argon-ion ( $1.5 \mathrm{~W}$ output power) or a krypton-ion laser tuned to $647.1 \mathrm{~nm}$ ( $100 \mathrm{~mW}$ output powcr) was used, the argon-ion laser being particularly suitable for $\mathrm{Ni}$ and $\mathrm{Cu}$ plating solutions and the krypton-ion laser being better suited to Au plating solutions. The laser was focused to spot sizes of 100-300 $\mu \mathrm{m}$ onto a dielectric substrate predeposited with a thin, absorbing metallic film. The predeposited thin film consisting of W, Mo, or Ni $1000 \AA$ thick both absorbed the optical energy and served as the cathode of the electroplating cell.

\subsection{Design and Construction of the Laser Photolysis System}

Based on this literature search a set-up for conducting laserassisted photolysis of gas-phase of organometallic compounds was designed and constructed. The system consists of a gas-fill and pumping station, as shown in Figures 2 and 3, which will be permanently installed in a chemical fume hood, and separate, portable sample chambers which will be evacuated, filled with the required organometallic compound, and carried to the laser for the photodecomposition experiments. A schematic of one of the sample chambers is shown in Figure 4. Separate sample chambers will be used for each different compound, thus reducing the risk of contamination. The gas-fill station is fitted with a heater assembly to enable it to be baked out and thoroughly degassed. The sample chamber will also have heating tape wrapped around it. Figure 5 shows a schematic of the experimental set-up for gas-phase photolysis. Over the next quarter extensive experiments will be carried out using this system to deposit some of the metals from the organometallic compounds listed in Table 2 . 


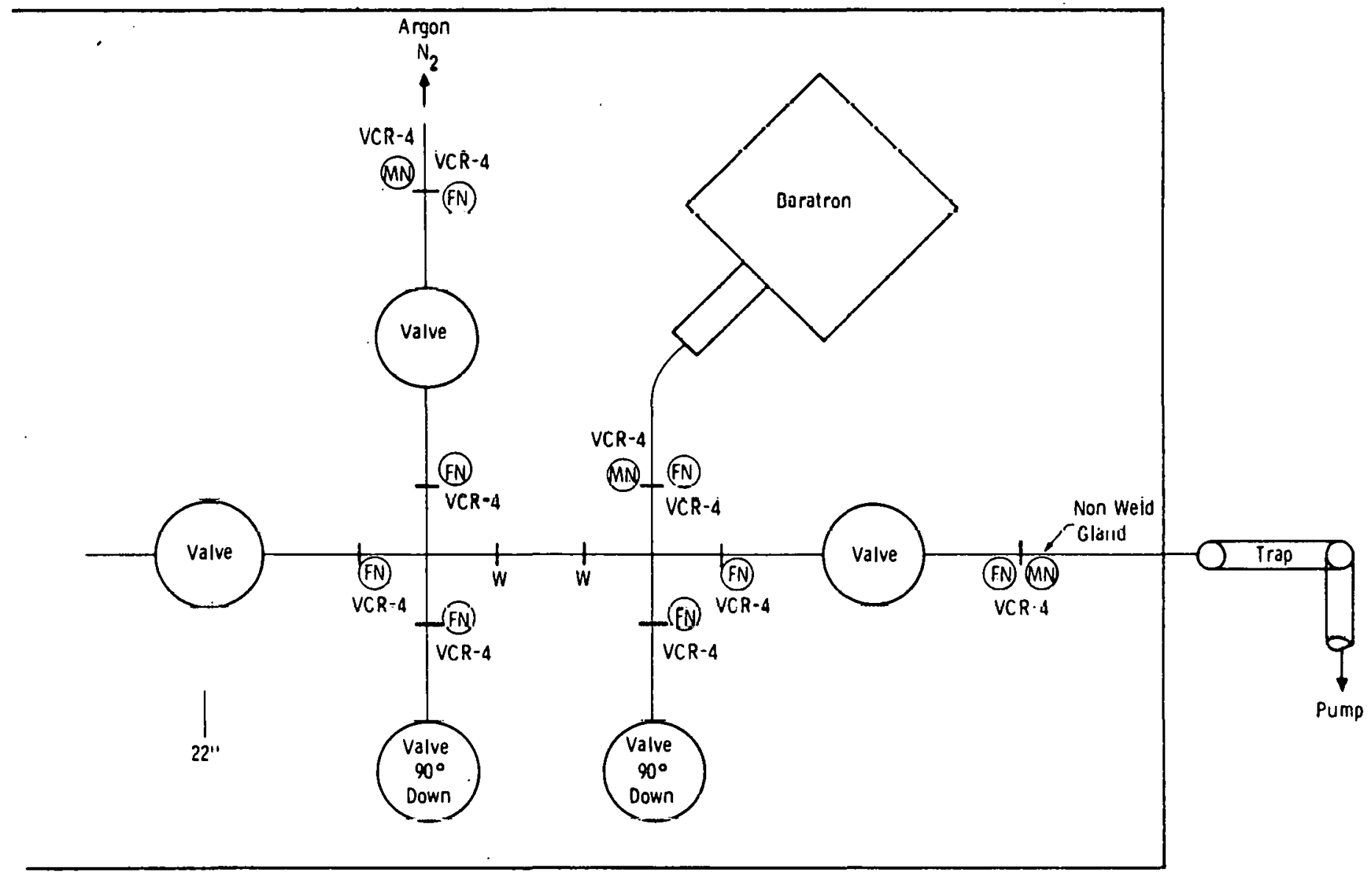

Figure 2. Top view of gas-fill and pumping station. 


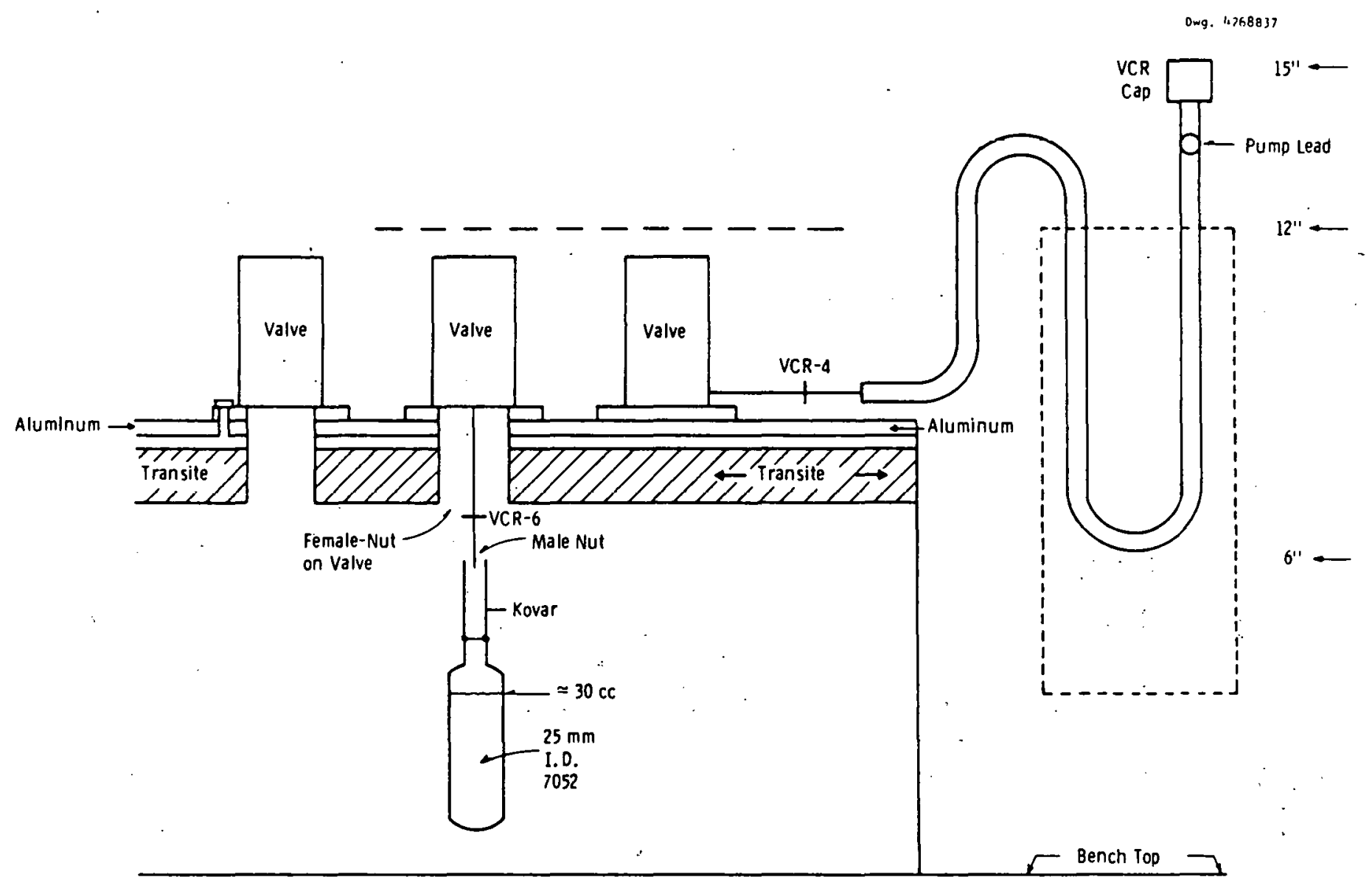

Figure 3. Cross section of gas-fill and pumping station. 


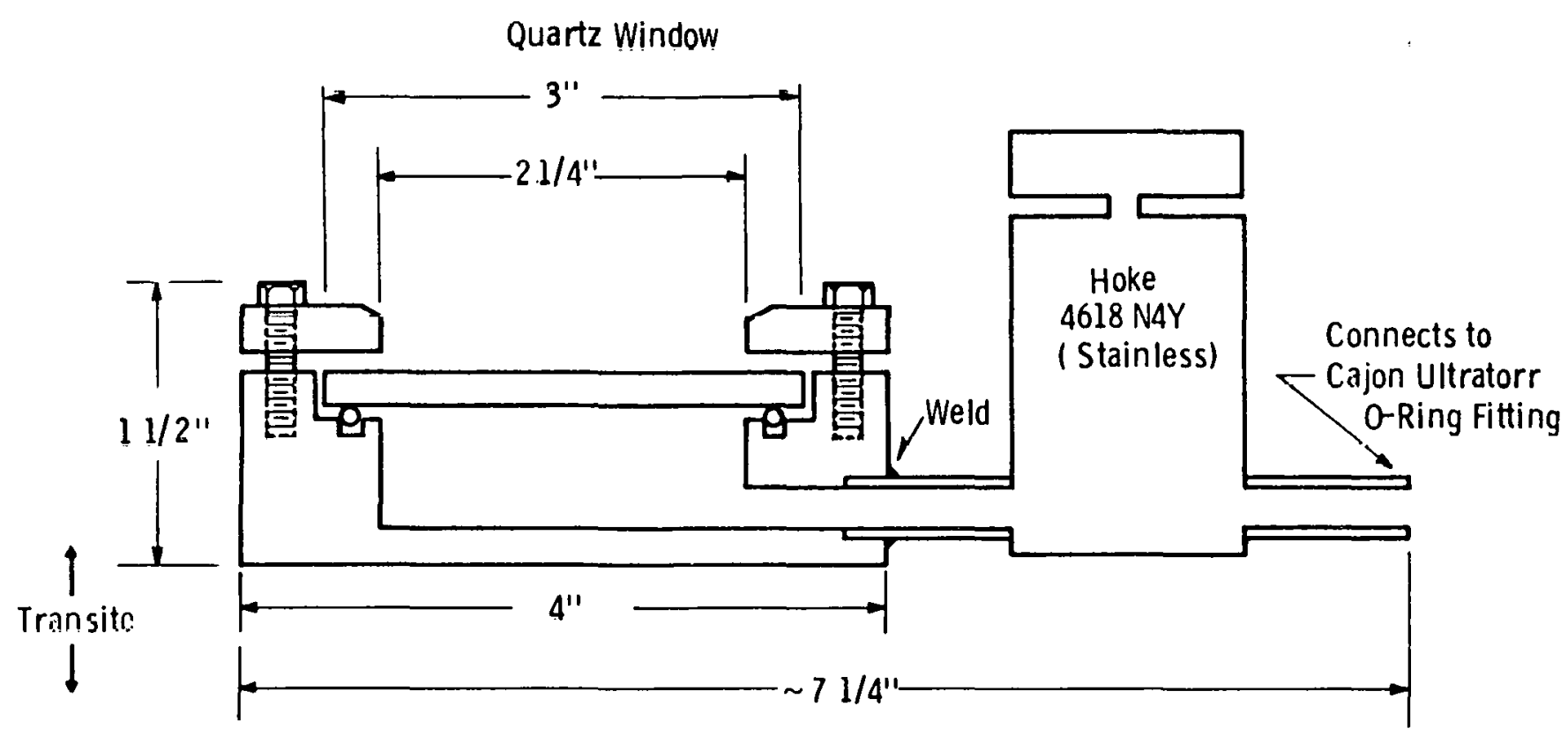

Figure 4. Schematic of sample chamber. 


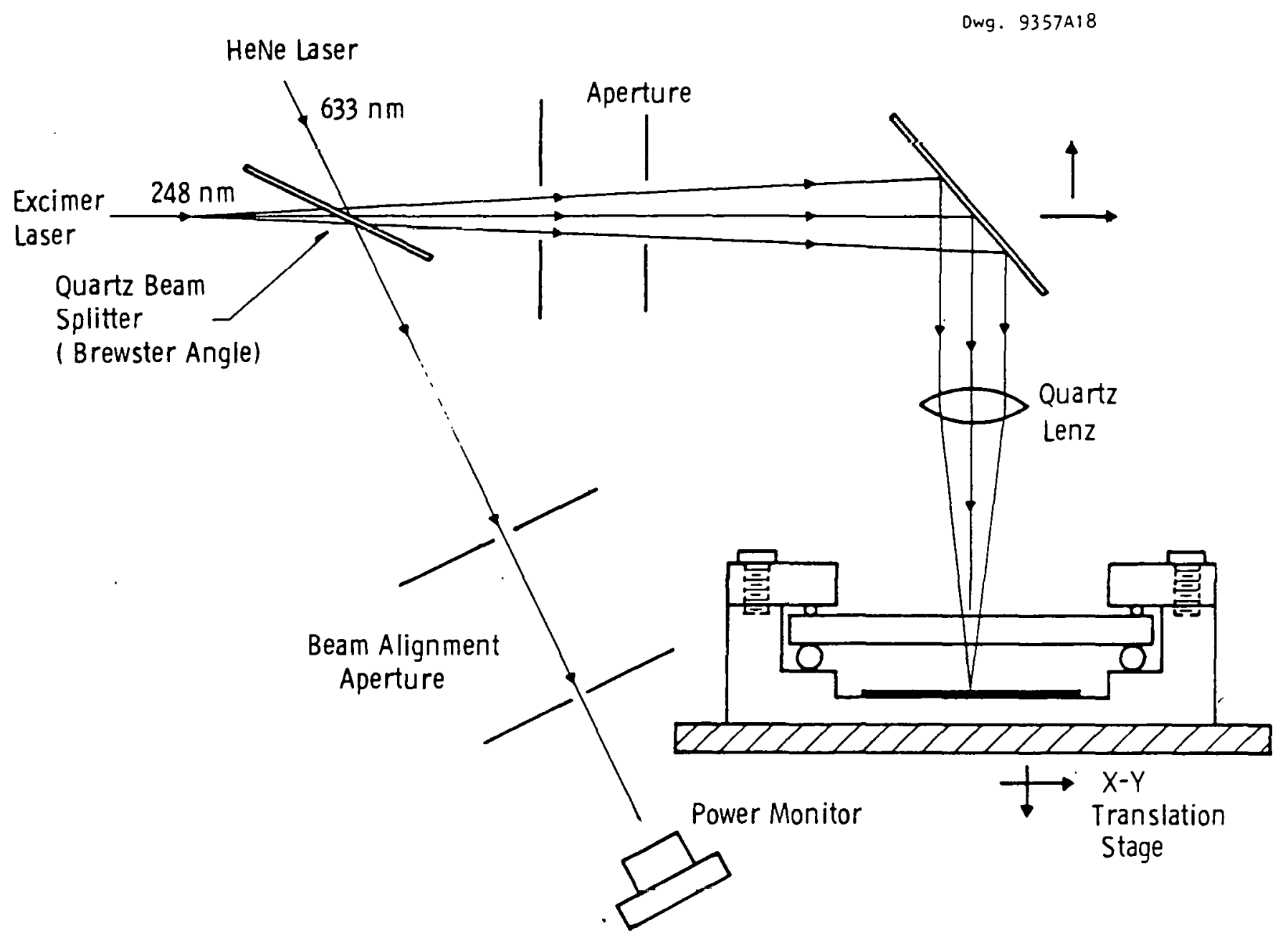

Figure 5. Schematic of experimental set-up for laser-assisted photolysis. 
Table 2

Sources of Useful Metals for Photovoltaic Applications

\begin{tabular}{|c|c|c|}
\hline Metal & Source & Properties \\
\hline Chromium & $\mathrm{Cr}(\mathrm{CO})_{6}$ & $\begin{array}{l}\text { Crystalline; m.p. } 110^{\circ} \text { decomposes; } \\
\text { density } 1.77\end{array}$ \\
\hline Mulybdenum & Mo $(\mathrm{CO})_{\dot{b}}$ & $\begin{array}{l}\text { Crystalline; m.p. } 150^{\circ} \\
\text { decomposes; b.p. } 156.4 / 766 \mathrm{~mm} ; \\
\text { denstry } 1.96\end{array}$ \\
\hline Nickel & $\mathrm{Ni}(\mathrm{CO})_{4}$ & $\begin{array}{l}\text { liquid; air-sensitive; m.p. }-25^{\circ} \text {; } \\
\text { b.p. } 43^{\circ} \text {; density } 1.32\end{array}$ \\
\hline Tin & $\left(\mathrm{CH}_{3}\right)_{4} \mathrm{Sn}$ & $\begin{array}{l}\text { liquid; m.p. }-54.8^{\circ} ; \text { b.p. } 78^{\circ} \text {; } \\
\text { density } 1.3149\end{array}$ \\
\hline Titanium & $\mathrm{Ti}\left[\mathrm{N}\left(\mathrm{CH}_{3}\right)_{2}\right]_{4}$ & $\begin{array}{l}\text { 1iquid; moisture-sensitive; b.p. } \\
50^{\circ} / 0.05 \mathrm{~nm} \text {; vap. press. } 8 \mathrm{~mm} / 80^{\circ} \mathrm{C}\end{array}$ \\
\hline Tungsten & $\mathrm{W}(\mathrm{CO})_{6}$ & $\begin{array}{l}\text { crystalline; m.p. approx. } 150^{\circ} \\
\text { decomposes; b.p. } 175 / 766 \mathrm{~mm} \\
\text { density } 2.65\end{array}$ \\
\hline
\end{tabular}

\subsection{Summary of Laser-Enhanced Electroplating Results}

Experiments on laser-enhanced electroplating were carried uut using a focused argon-ion laser, x-y scanning mirrors, a copper plating solution, and silicon wafers coaled with evaporated titanium-palladium layers. Details of the experiment are presented in section 1.3.1. The laser power, focussed spot size, plating current, and volume of elecliulyte-were all varied to determine the finest line that could be plated. The plated spots and lines were characterized by Nomarski microscopy and Talystep profiling. A $1 \mathrm{~cm}$-long, dense, uniform line, $25 \mu \mathrm{m}$ wide and $6000 \mathrm{~A}$ thick, was plated using a mirror scan rate of $25 \mathrm{~cm} / \mathrm{sec}$, a total exposure time of $25 \mathrm{sec}$, a laser power of $4 \mathrm{~W}$, and a negative plating current of $1 \mathrm{~mA}$. A dramatically high plating rate of $12 \mu \mathrm{m} / \mathrm{sec}$ was achieved using this technique. 


\subsubsection{Experimental Details}

Details of the experiments on laser-enhanced electroplating and a summary of the data obtained are presented in this section.

The electrolyte used was a copper plating solution of the following composition: $37.4 \mathrm{~g} \cdot \mathrm{CuSO}_{4} \cdot 5 \mathrm{H}_{2} \mathrm{O}$ and $4.2 \mathrm{ml} \cdot \mathrm{H}_{2} \mathrm{SO}_{4}$ in $200 \mathrm{ml}$. de-ionized water. Electroplating was carried out on 2-inch silicon wafers coated with thin films of evaporated metal -- $1000 \AA$ titanium, $1000 \AA$ palladium, and a two-layer system of palladium on titanium, each 1000 \& thick. Plating was observed to occur only on the two-metal system -- the titanium alone could not be plated upon, and the palladium alone did not adhere to the silicon surface. An insulated wire was attached to each wafer surface with silver epoxy, allowing the wafer to be used as the cathode of the electrolytic cell. A copper strip was used as the anode. The wafer was placed flat in a shallow dish containing the electrolyte. A multimode argon-ion laser was focussed to a $30 \mu \mathrm{m}$ spot onto the wafer surface. The laser spot could be scanned across the wafer by $x-y$ mirrors.

Careful experiments were carried out to determine the factors affecting the size of the plated region. Plating current, laser power, focal distance, and level of electrolyte were all varied to determine the effect of each on the plated spot size. Using ac bias caused the plated spots to deplate with time, so negative bias was used. At higher laser powers, the electrolyte would start boiling, thus broadening the plated spot. The size of the spot was also found to be proportional to the plating current and the volume of electrolyte. The dependence on focal distance was weak at higher laser powers and plating currents, but became much sharper when the laser power and plating current were reduced to minimal values.

The smallest spot plated with a total laser exposure time of $5 \mathrm{sec}$ was $80 \mu \mathrm{m}$, as shown in Figure 6. The laser power used was $4 \mathrm{~W}$ and the plating current applied was $1 \mathrm{~mA}$. 


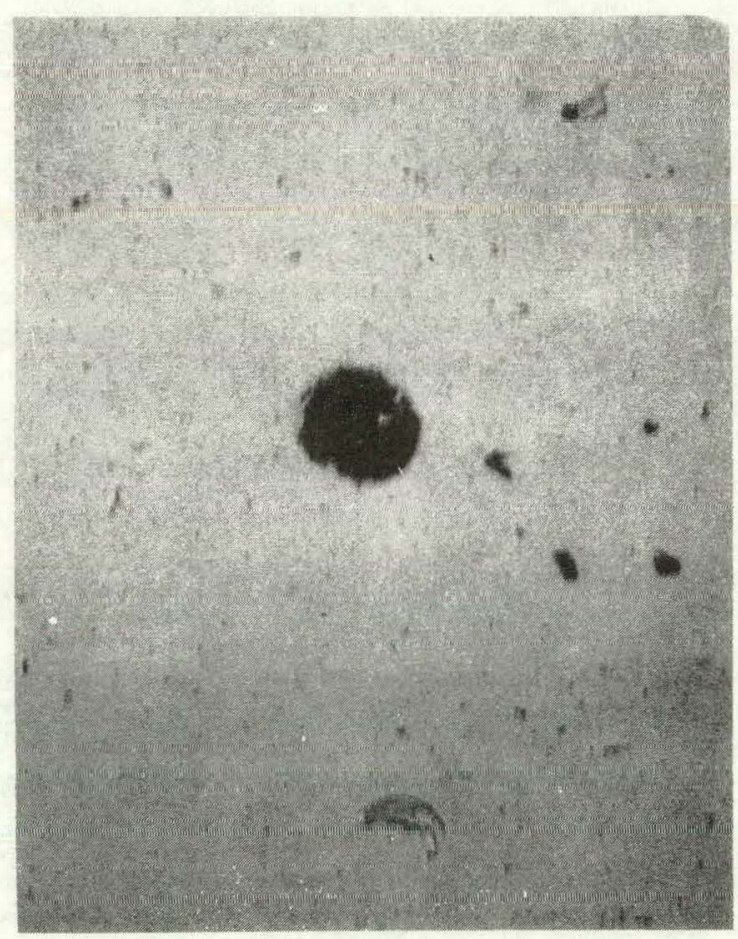

Figure 6. 150X Nomarski micrograph of line plated using sing1e slow scan. 
Using the $\mathrm{x}$ and $\mathrm{y}$ scanning mirrors, plated lines were written. In one experiment, one of the mirrors was scanned a single time over $1 \mathrm{~cm}$, the scan period being $25 \mathrm{sec}$. The laser power and plating current were $4 \mathrm{~W}$ and $1 \mathrm{~mA}$, respectively. The plated line was somewhat uneven, varying in width from $40-60 \mu \mathrm{m}$, as shown in Figure 7 , with a thickness of approximately $3000 \AA$, as determined by Talystep profiling.

The finest and densest line was plated using a rapid scan rate of $25 \mathrm{~cm} / \mathrm{sec}$ over a total exposure time of $20 \mathrm{sec}$. A laser power of $4 \mathrm{~W}$ and a plating current of $2 \mathrm{~mA}$ were used. The $1 \mathrm{~cm}-1$ ong plated line was $25 \mu \mathrm{m}$ wide, $6000 \AA$ thick, and very even along its entire length, as shown in Figure 8. A plating rate as high as $12 \mu \mathrm{m} / \mathrm{sec}$ was achieved with this line.

The laser-enhanced electroplating experiments have yielded exciting results. If time permits, it would be interesting to pursue further experiments along these lines using a silver plating solution. 


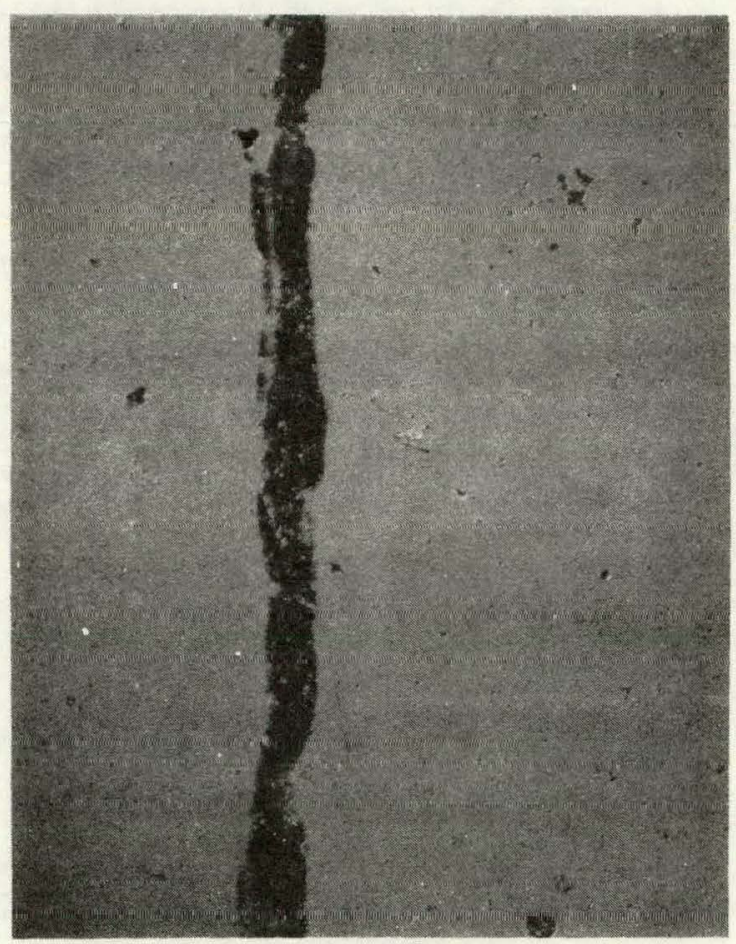

Figure 7. 100X Nomarski micrograph of line plated using single slow scan. 


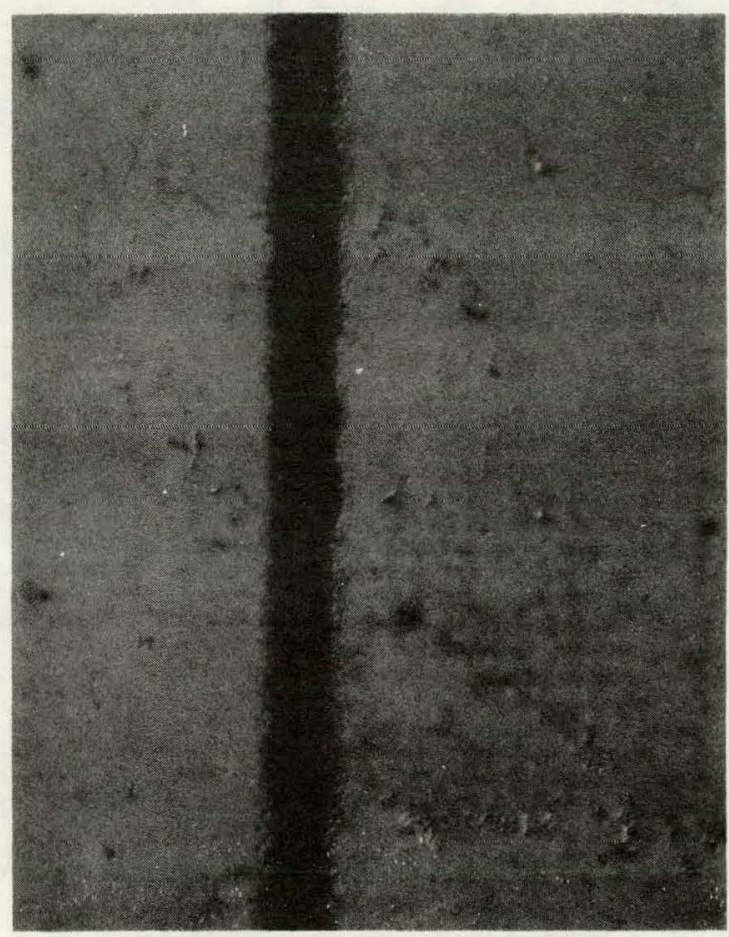

Figure 8. 200x Nomarski micrograph of line plated using multiple rapid scans. 


\section{CONCLUSIONS AND RECOMMENDATIONS}

The literature survey of the current state-of-the-art laser metallization schemes indicates that the excellent surface adhesion, the quality of the metal deposited, the cleanliness of the system, the ability to direct-write a metal pattern, and the fine-line resolution obtained make such systems particularly attractive for solar cell metallization. Another advantage of laser-assisted metallization for photovoltaic applications is the in-situ, localized sintering that takes place, shallow junction degradation being avoided because of the very short laser wavelengths used. The major drawback to laser-assisted pyrolytic and photolytic metal deposition from gas-phase compounds may be the relatively slow deposition rates. A detailed evaluation of the economics of the direct-write versus the mask/flood illumination techniques will be made, and the experiments on gas-phase photolysis carried out in the next quarter will be used to refine the preliminary evaluation. In the meantime, it appears that laser-assisted deposition from the liquid phase may be particularly promising because of the much higher deposition rates expected. Experiments using a laser to thermally decompose spin-on metal-bearing polymer films and metalloorganic inks are planned for the next quarter.

The promising results of the laser-enhanced electroplating experiments have opened up yet another possibility. The initial diffusion barrier layers may be deposited over the entire wafer by flood illumination-enhanced photolysis, with subsequent laser-assisted electroplating being used for pattern definition. This technique would have the advantage of having the entire silicon surface protected by the diffusion barrier during electro-plating, the unplated regions being etched away later. 


\section{PROJECTION OF ACTIVITIES FOR SECOND QUARTER}

A preliminary evaluation of the economics of the laspr metallization schemes under study will be made. Extensive experiments on metal deposition by excimer laser-assisted photolysis of gas-phase organometallic compounds will be carried out using the system described in Section l.2. The direct-write and mask/flood illumination techniques for patterning will be compared. Laser-assisted pyrolytic decomposition of liquids will be studied. Metallo-organic silver inks and spin-on metal-bearing polymer films will be used for these experiments. If time permits, the laser-enhanced electroplating experiments may be continued using silver plating solutions. 


\section{REFERENCES}

1. C. W. Draper, J. Phys. Chem. 84,2084 (1980); Met. Trans. 11A, 349 $(1980)$.

2. R. Solanki, P, Boyer, .J. E. Mahan, and G. J. Collins, Appl. Phys. Letet $38,572(1981)$.

3. T. F. Deutsch, D, J. Ehrlich, and R. M. Osgood, Jr., Appl. Phys. Letr. 35, 175 (1979).

.4. D. J. Ehrlich, R. M. Osgood, Jr., and T. F. Deutsch, App1. Phys. Lett. $38,946(1981)$.

5. D. J. Ehrlich, R. M. Osgood, Jr., and T. F. Deutsch, J. Electrochem. Soc. 128,2039 (1981).

6. D. J. Ehrlich, R. M. Osgood, Jr., and T. F. Deutsch, J. Vac. Sci. Technol. $21,23(1.981)$.

7. R. D. Coombe and F. J. Wodarczyk, Appl. Phys. Lett. 37, 846 (1980).

8. S. D. Allen, LEEE J. Qauntum Eleclrull. QE-15, 43D (1979); S. D. Allen and M. Bass, J. Vac. Sci. Technol. 16, 431 (1979).

9. R. J. von Gutfield, E. E. Tynan, R. L. Melcher, and S. E. Blum, Appl. Phys. Lett. 35,651 (1979). 